\title{
Lactate modulates gene expression in human mesenchymal stem cells
}

\author{
Derek Zieker • Richard Schäfer • Jörg Glatzle • \\ Kay Nieselt • Stephan Coerper • Torsten Kluba • \\ Hinnak Northoff • Alfred Königsrainer • \\ Thomas K. Hunt • Stefan Beckert
}

Published online: 11 November 2008

(C) Springer-Verlag 2008

Erratum to: Langenbecks Arch Surg (2008)

DOI 10.1007/s00423-008-0286-6

The name of one of the co-authors was omitted from the manuscript submitted for publication.

The complete authorship is given here.

The online version of the original article can be found at http://dx.doi. org/10.1007/s00423-008-0286-6.

D. Zieker $(\bowtie) \cdot$ J. Glatzle $\cdot$ S. Coerper $\cdot$ A. Königsrainer

S. Beckert

Department of General and Transplant Surgery,

University of Tuebingen,

Hoppe-Seyler-Strasse 3,

72076 Tuebingen, Germany

e-mail: derek.zieker@med.uni-tuebingen.de

R. Schäfer $\cdot H$. Northoff

Department of Transfusion Medicine, University of Tuebingen,

Tuebingen, Germany

K. Nieselt

Center for Bioinformatics Tuebingen,

Department of Information and Cognitive Sciences,

University of Tuebingen,

Tuebingen, Germany

T. Kluba

Department of Orthopaedics, University Hospital Tuebingen,

Tuebingen, Germany

T. K. Hunt

Department of Surgery, University of California,

San Francisco, CA, USA 